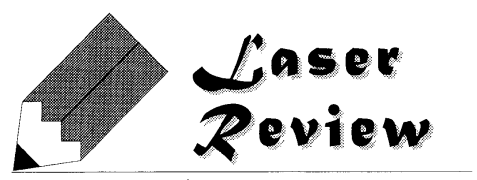

\author{
連続発振アルゴンイオンレーザーの共振器内周波数逓倍 \\ 平洋一, 末岡 邦昭 \\ 日本アイ・ビー・エム 株) 東京基礎研究所 (テ242-8502 神奈川県大和市下鶴間1623-14)
}

\title{
Intra-Cavity Frequency Doubling of CW Argon Ion Lasers
}

\author{
Yoichi TAIRA and Kuniaki SUEOKA \\ IBM Research, Tokoyo Research Laboratory, 1623-14 Shimotsuruma, Yamato, Kanagawa 242-8502
}

(Received May 17, 1999)

\begin{abstract}
Over one-watt continuous coherent light in a quarter micrometer wavelength region is obtained by the frequency doubling of ion lasers and solid state lasers. It is shown experimentally as well as theoretically that more than a half of the fundamental output of the source laser is converted to the UV light when the intracavity loss is sufficiently low. The applications of such UV light are also discussed.
\end{abstract}

Key Words: Frequency doubling, CW ion laser, SHG, BBO, CLBO

1.はじめに

非線型光学効果を用いたレーザーの波長变換は直接発 振が得にくい領域でのコヒーレント光を得るのに有効で ある。このような領域のひとつとして連続な紫外光領域 があるが,これは微細加工や,ポリマー加工そのほか, 多く の興味ある応用が広がっている分野でもあり,特別な特徴 を有する紫外光源があればそれに対応する応用分野が開 けてくることが期待される.

一般に非線型光学効果による波長変換の変換効率はき わめて小さい1). 最も効果の大きい2次の非線型光学効果 である2倍波の発生においても, 飽和を無視すれば, 出力パ ワーは入射光パワーの 2 乗に, 変換効率は1乗に比例するの で,効率を上げるには入射光のピークパワーを上げる必要 がある2). しかし連続光ではパルス光と異なり, 平均パ ワーがピークパワーに等しいので,高い変換効率を得るに は, 共振器内派倍技術を用いることが必要になる。

可視光の聥倍としてはじめの頃は冷却したKDPやADP の結晶を用いたレーザー共振器内聥倍が用いられたが, 結 晶の温度安定性や光吸収などのため, 得られる2倍波パワー には限界があった3)。その後, 新しい $\mathrm{BBO}^{4)}$ など低損失で光 強度に強い新世代結晶が試みられたが, 基本波出力が数W 級のアルゴンイオンレーザーを用いても5) $1 \mathrm{~W}$ 超えるこ とは簡単ではなかった。 そこで, 共振器内逓倍において高 出力を得る条件について改めて考察し, 実験を行なった結 果を, 以下に述べる。
2. 共振器内波長変換モデル

一般に,有限のビーム径のレーザー光を用いて非線型光 学結晶によって2倍波の発生を行なうとき,光が理想的なコ ヒーレント光であり, 結晶の光強度による損傷が無視でき るなら, 最適な集光条件が結晶の大きさによって決められ る.このとき得られる最大の変換効率は結晶の性質だけ で決まり,結晶の大きさにはよらず，一定である6)．実際， 連続可視光の倍波を発生させると倍波のパワーを $P_{\mathrm{sh}}$ 基本 波パワーをPとするとき

$$
P_{\mathrm{sh}}=\eta P^{2}
$$

の関係があるが,ここで, 可視光を基本波とするときの波 長変換係数 $の$ 值は結晶への基本波の集光条件や光のコ ヒーレンスによって異なるが, 最善の場合でも, 角度位相 整合のBBO結晶等の場合 $10^{-4} \mathrm{~W}^{-1}$, より非線型効果の大きな $\mathrm{KTP}$ 結晶等の場合 $10^{-3} \mathrm{~W}^{-1}$ 程度である7). したがって, 高効 率の結晶の場合でも $1 \mathrm{~kW}$ 以上の入射光を用いなければ, 1 に近い十分な変換効率は得られないことになる2)。しか し, 連続光の場合には, 共振器によって, 波長変換素子内の 光パワーを上げることができる。つまり,スペクトル幅が 狭いという特徴を生かせば, 基本波のパワーを共振器内に 閉じ込めて $K$ 倍のパワーにして共振器内で 2 倍波を発生さ せれば, 出力および変換効率は $K^{2}$ 倍となり, 高い変換効率 が実現できる11.

Fig.1のように共振器内に連続な基本波を導き入れれば, 扔拉よそ共振器の共振帯域幅と同等までの周波数幅の レーザー光を共振器に閉じこめることができる。した がって, 連続レーザー光の波長変換では, 共振器を用いる 


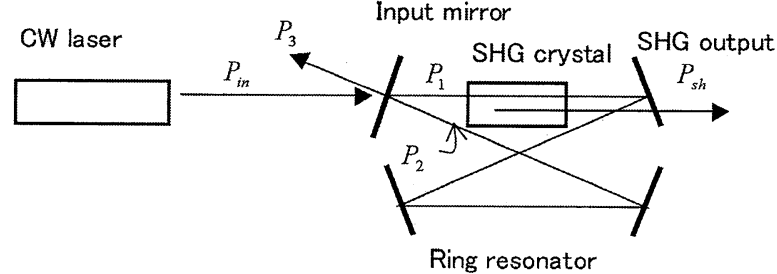

Fig.1 Frequency doubling using an external ring resonator. $P_{\text {in }}, P_{1}, P_{2}, P_{3}$ and $\mathrm{P}_{\mathrm{sh}}$ are: fundamental input power, power before SHG crystal, power before the coupling mirror, and output SHG power, respectively.

ことによって基本波の単位周波数帯域あたりのパワー,つ まり輝度が大きいという特徴を生かした高効率の波長変 換が実現できることとなる．共振器として,レーザーの外 に置いた外部共振器を用いる場合と,レーザーの共振器そ のものを用いる場合とがある．外部共振器に光を閉じ込 めるには, 外部共振器とレーザー光の周波数のマッチング をとらなければならない.このためには,2つの周波数の同 調状態を検出する方法と,レーザーあるいは外部共振器の 周波数を同調する機構が必要になる。また,レーザー光を 共振器にカップルさせ,十分にレーザーパワーが共振器に 導き入れられるようにするには,レーザー光と外部共振器 の横モードもマッチングさせなければならない.このた めの技術として, 周波数同調の検出法や, 横モードのマッ チング法についての進展もあるが, 詳しくは別の機会に述 ベたい. 一方, レーザー共振器内での波長変換では, レー ザーの発振状態が共振している状態であり, 可視のレー ザーでは, 共振器長を調整して周波数を合わせなくても発 振状態になる。しかしながら,レーザー増幅器内でのモー ド体積を最適化し,かつ波長変換素子内のビーム径や集光 条件を適切にするための共振器設計は, レーザー共振器内 での波長変換においても重要である.

さてFig.1のような配置の外部共振器に基本波のレー ザー光を導き入れる場合について簡単なモデルを作って みる、レーザーの基本波パワー $P_{\text {in }}$ 基本波のパワー反射 率 $R$, 透過率 $T$ の 1 つ入射鏡と, 基本波を全反射し, 2 倍波を 100\%透過する3つの鏡を用いて共振器を構成して基本波を 閉じ込めることとする．共振器長は入射光の周波数に完 全に同調しており,横モードも完全に一致していると仮定 する. このとき, 入射鏡の前後での共振器内の基本波およ び入射鏡で反射される入射光のパワーをそれぞれ $P_{2}, P_{1}$, $P_{3}$, それぞれの電場の振幅を $E_{2}, E_{1}, E_{3}$, また入射光の振幅 を $E_{\text {in }}$ と表すとすれば, 入射鏡の振幅反射率 $r\left(r^{2}=R\right)$ および 振幅透過率 $t\left(t^{2}=T\right)$ を用いて, 電場の振幅の間に次の関係 が得られる。

$$
\begin{aligned}
& E_{1}=r E_{2}+t E_{\text {in }} \\
& E_{3}=-r E_{\text {in }}+t E_{2}
\end{aligned}
$$

これから，基本波パワーの入射鏡の前後での増分 $\Delta P=P_{1}-P_{2}$ は, $P=P_{1} \cong P_{2}$ を用いて

$$
\Delta P=-(1-R) P+2 \sqrt{R T} \sqrt{P_{\text {in }}} \sqrt{P}+T P_{\text {in }}
$$

となる。

さらに基本波が共振器内を一周するときの吸収・散 乱・反射による損失の割合を $A$ とすると, 2 倍波に変換され るパワー $P_{\mathrm{sh}}$ は, 共振器一周したときの基本波パワーが保存 する条件 $\Delta P=A P+P_{\mathrm{sh}}$ から

$$
P_{\mathrm{sh}}=2 \sqrt{R T} \sqrt{P_{\text {in }}} \sqrt{P}-(1-R+A) P+T P_{\text {in }}
$$

と求められる。 この解は式 $(1),(5) を P_{\mathrm{sh}}$ をPの関数として 2つのグラフを描いたときの交点として求められる. Fig.2 に $P_{\text {in }}=1 \mathrm{~W}, R=0.99, T=0.01$ としたときのグラフをいくつ かのAの值について示す。これから, 共振器の入射鏡反射 率の設定が適切で, 共振器の基本波の損失が十分少なけれ ば十分高い効率での変換が可能であることがわかる。な お,式(3)の值をゼロとおけば, 入射レーザー光がすべて共 振器に入る条件,

$$
R P_{\text {in }}=T P
$$

が求まる．このような外部共振器を用いる場合，いかに入 射光の周波数と横モードを共振器のそれと一致させるか が課題となり, 共振器長の制御, 横モードの同調について 多くの興味ある成果が得られているが,これらについては 別の機会に述べる.

連続発振のレーザー共振器内での波長変換について Fig.3のようなモデルを用いて考える。簡単のため, 発振 モードはひとつの軸モードだけとする。すると, 共振器を 一周するときの基本波パワーの増分は, 増幅媒質による増 幅から, 2倍波発生によるパワー変換および線形の損失を引 いたものになる．増幅によるパワーの増加は, 増幅定数 $G$ および, 飽和出力パワーSを用いて $G S P /(S+P)$ と表され る. 一方,一周したときの吸収・散乱・反射による線形損 失の割合を $A$ とおけば, 定常状態での基本波パワーは変わ らないことから

$$
P_{\mathrm{sh}}=\frac{G S P}{S+P}-A P
$$

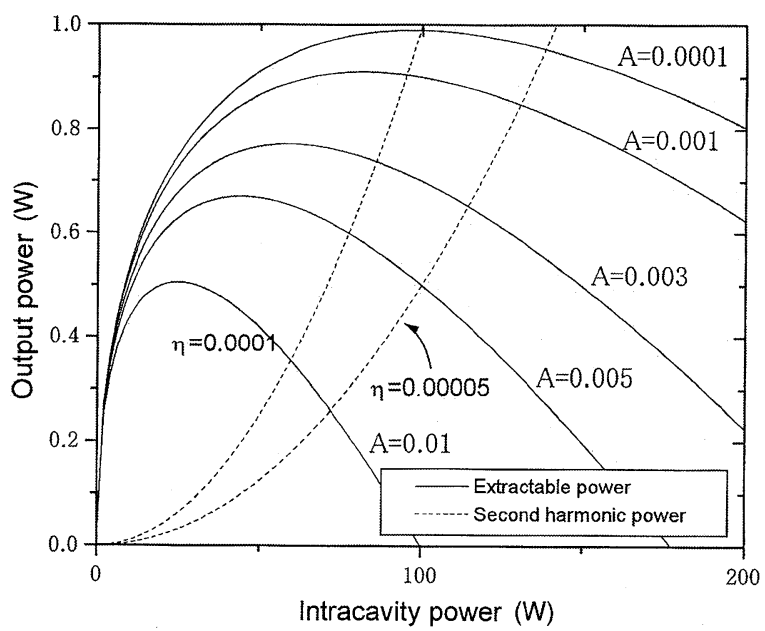

Fig.2 Determination of the operating condition of SHG using an external resonator. The operating point is obtained as the intersection of parabolic SHG output and the extractable power curve from Eq. (5). 


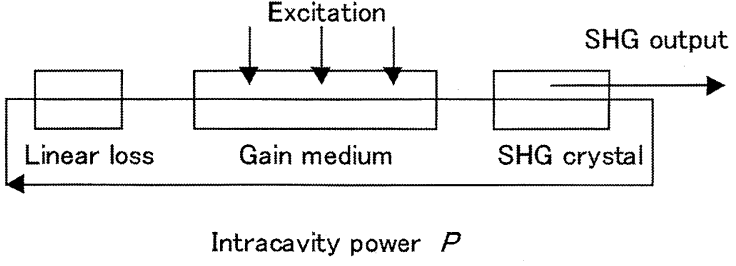

Fig.3 Model of intracavity doubling of CW laser.

ここで通常のイオンレーザーのような往復型の共振器で は基本波は一往復につき非線型結晶を 2 度通るので, 取り出 される2倍波パワー $P_{\mathrm{sh}}$ は2倍になり，

$$
P_{\mathrm{sh}}=2 \eta P^{2}
$$

となる.この式 (7), (8)の解は先ほどと同様, Fig.4に示す ように $P_{\mathrm{sh}}$ をの関数として式(7), (8)のグラフを描き,その 交点を求めることによって得られる. Fig.4は $S=100 \mathrm{~W}, G$ $=0.2$ の場合を示す.Fig.4において一点鎖線で示した直線 は, 非線型結晶の代わりに内部パワーの5\%を取り出せるよ うな出力鏡を置いた場合をあらわし, 通常の基本波出力は この直線と式 (7)の交点が動作点となる。したがって,2倍 波変換係数の值が適切で, 非線型光学結晶および光学系の 追加による線形損失が同じならば, 原理的には共振器内逓 倍の出力は, 基本波出力と同じになる．共振器内聥倍では この 2 つ出力の比を便宜的に実効効率と呼ぶことがあ る. BBO結晶によるアルゴンイオンレーザー共振器内で の2倍波発生によって, 1Wを超える十分なパワーを得るに は, 線形損失を減らして, 共振器内パワーが100Wを超える ようにする必要があることがわかる。なお,式(7), (8)の 解析解は,

$$
P=-\frac{A}{4 \eta}-\frac{S}{2}+\frac{1}{4 \eta} \sqrt{8 G \eta S+(A-2 \eta S)^{2}}
$$

となるまた,2倍波パワーを最大にする最適な非線型係数 の条件は

$$
\eta=\frac{A}{2 S}
$$

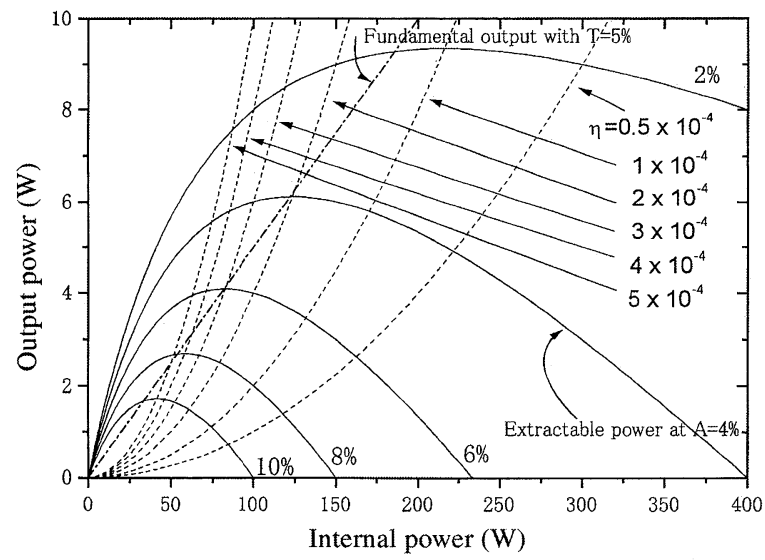

Fig.4 Determination of the operating condition of an intracavity doubled laser. The operating point is obtained as the intersection of parabolic SHG output and the extractable power curve from Eq. (9).
であり,この時の共振器内パワーおよび2倍波出力パワーは 次のように得られる。

$$
P=S(\sqrt{G / A}-1), \quad P_{\mathrm{sh}}=S(\sqrt{G}-\sqrt{A})^{2}
$$

Gはレーザー媒質の構造と励起条件によって一義的に決ま るが, Sはレーザー媒質内のモード体積にほぼ比例するの で, 非線型結晶を含むレーザー共振器は, 非線型結晶内で の基本波のビーム形状を最適にしてかつレーザー媒質の モード体積を十分取れるように設計する必要がある。実 はFig.6のような配置は, 2つの凹面鏡の距離を適切に調整 することによって,この条件を満たすことができる。

\section{3. イオンレーザーの共振器内周波数派倍}

共振器内聥倍では基本波のパワーの増大には共振器内 素子による光損失を減らすことが重要である。このよう なレーザー共振器内逓倍掞よび, 外部共振器内聥倍は, 簡 単なモデルで特性を表現でき, 装置を設計することができ る。実際, BBO, LBO, CLBOといった結晶の基本波損失は 非常に少なく, 損失源としては, 誘電体ミラーの散乱・吸 収と, 結晶表面の反射損失, そしてレーザー媒質内の吸収 が主なものとなる．損失 1 万分の 1 以下という誘電体鏡も 利用可能であるので, 共振器内での光学部品の低損失化が 高効率のための重要な条件となる8).

これまでに, Fig.5の配置の実験ではBBOを用いた大型の アルゴンイオンレーザーの共振器内逓倍によって, $257 \mathrm{~nm}$ での単一ビーム出力 $3 \mathrm{~W}$ (両方向で6W)が得られている。こ のレーザーは基本波の出力として10Wを出すことができる ので, 実効効率として $60 \%$ が得られたことになる。また同 じ装置を用いた実験において, 244nmで一方向で $1.2 \mathrm{~W}$, 両 方向の和で $2.4 \mathrm{~W}$ が得られている. Fig.6は長さ $6.5 \mathrm{~mm}$ の BBOによって $257 \mathrm{~nm}$ で一方向3Wの出力を得た実験結果で あり ${ }^{9)}$, 両方向に出る紫外光パワーの和を縦軸にとってあ る.CLBOではFig.7に示すようにBBOの約1.4倍の変換効 率が得られた ${ }^{10)}$ 。なおBBOの場合受容角が小さいため, 楕 円形の周りに周期的な細い縞状のリップルが乗った断面 形状を持った出力光となる. Fig.8に示すような円筒鏡を 用いた共振器を用いることで断面形状を円形に近づける ことが可能であり, 光学系の複雑化に伴う損失の増大など

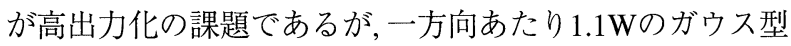
のビーム形状の $257 \mathrm{~nm}$ 出力が得られている91.

このような高効率の共振器内波長変換において, 実用時 の問題は紫外出力の時間的な低下である. 実際, 現在数 $100 \mathrm{~mW}$ ま゙の257nmのBBOを用いた紫外出力の装置では,

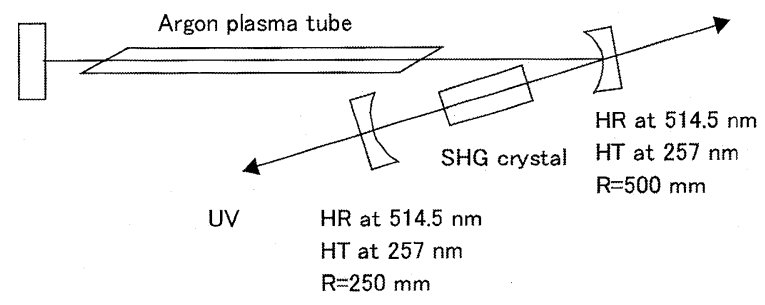

Fig.5 Experimental setup for an intracavity doubling of an argon ion laser. 


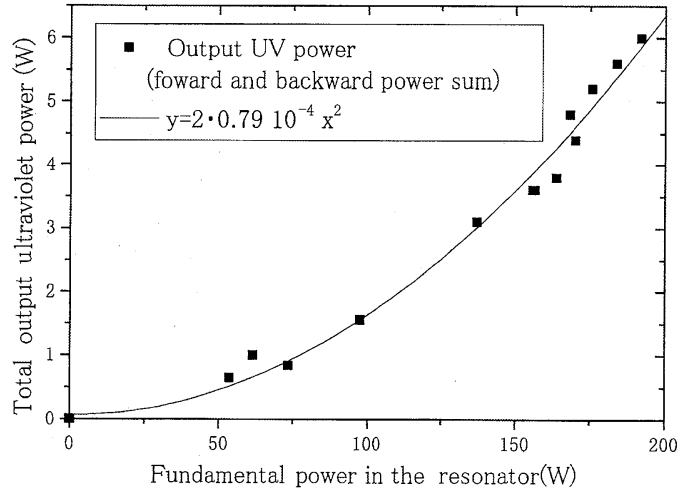

Fig.6 Experimental result of an intracavity doubling of an argon ion laser. Maximum SHG output at $257 \mathrm{~nm}$ of $6 \mathrm{~W}$ was recorded by using a BBO crystal as the SHG crystal.

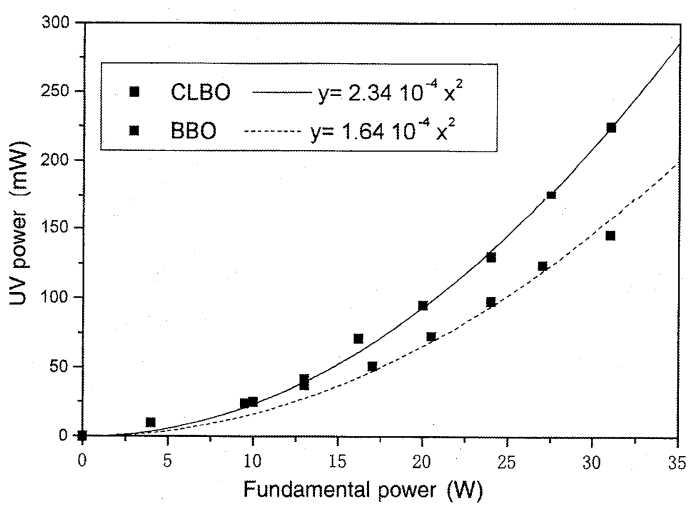

Fig.7 Comparison of the intracavity doubling outputs by $\mathrm{BBO}$ and $\mathrm{CLBO}$.

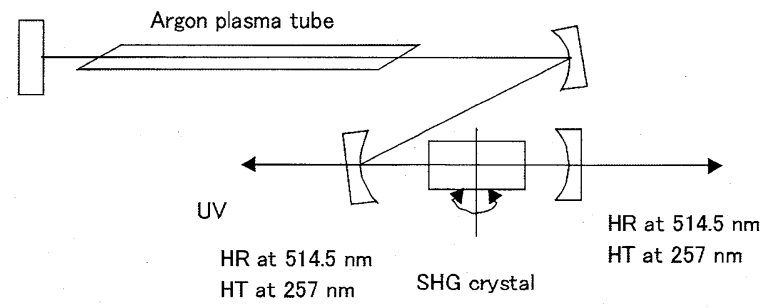

Fig.8 Experimental setup of an intracavity doulbing of an argon ion laser using elliptical focusing.

毎日 5 時間運転しても, 1 年以上の期間にわたって紫外光が 得られるが $1 \mathrm{~W}$ 以上の動作では出力パワーが1日単位で低 下する。な㧍, 結晶内の損失が十分小さく,劣化が光強度 による場合, 結晶を大きくすれば, 寿命を延ばすことは原 理的には可能である。たとえば, ある結晶でのビーム径が wであるとすると,結晶の大きさを $a$ 倍したときの同じ変換 条件を与えるビーム径は $a w$ となる。，そこで高品質の大き な結晶を作ることができれば,結晶内の基本波強度を十分 に下げることが可能となる。発生した紫外光吸収による 劣化も同様に減らすことができるので, 大出力を長時間安 定に出すためには大型の良質の結晶が鍵になる.

BBOは高強度の基本波で劣化することもあったが,この 点は最近著しく改良された。より問題なのは紫外光の吸 収による劣化である.結晶の劣化が紫外光の吸収による
温度上昇で起こるのか, あるいは電子励起状態を経て結晶 内にカラーセンター等ができるのかは定かではないが, 結 晶の製造元や製造時期にこの劣化特性が大きく依存し,非 常に劣化の少ないものもある。したがって,より高度な不 純物制御, あるいは新しい結晶材料の開発によって劣化特 性が改善されることを期待している。これまでのところ CLBO結晶ではこの紫外光による影響が顕著であり, $257 \mathrm{~nm}$ においても安定な出力を得るにはFig.9のような結晶の振 動装置を用いて約 2 秒周期で, 結晶を光軸と垂直方向に振動 させることが必要であった10)。またある特定のBBO結晶 を用いたアルゴンレーザーの遁倍装置において窒素パー ジによって紫外出力が数時間で低下する現象を確認し た．窒素パージをせず通常の空気中では,このような現象 は起こらず, BBO結晶表面から酸素がなくなることが原因 との指摘もあるが11), 結論を出すにはまだ研究が必要であ る.

\section{4. 紫外光の応用}

連続でコヒーレントな紫外光源は, 指向性が高く,また 偏光度の高い光源であり, 周波数幅をせばめることも容易 である。この特徴を応用して,フォトリソグラフィ, 顕微 鏡による微細構造の観察,材料の表面改質たとえば液晶の 配向膜の加工 ${ }^{12,13)}$, ホログラム作成, ファイバ内や平面状の 回折格子作成, 3次元リソグラフィとも呼ばれる光硬化樹脂 を用いた 3 次元形状の形成などへの利用が行われている. パルスのフォトリソグラフィではスペックルを平均化す るため拡散条件を変えて多数ショットの露光が行なわれ るが,連続光では,より簡単にスペックルが平均化できる. いずれにしても,広範な応用のためにはさらに結晶の寿命 を上げ,装置としての信頼性を上げることが重要であると 思われる。

\section{5. まとめ}

イオンレーザーや連続発振固体レーザーの共振器を用 いた周波数派倍によって, $1 \mathrm{~W}$ 以上の連続な $0.25 \mu \mathrm{m}$ 領域の 波長のコヒーレント光を得られる. 共振器内は周波数逅

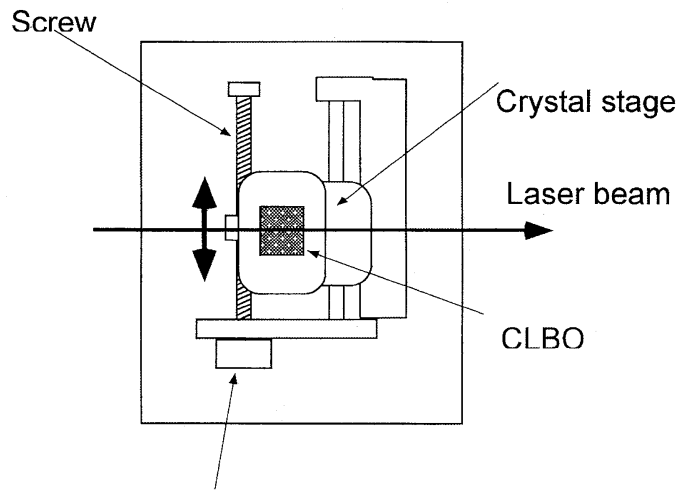

Stepping motor

Fig.9 Mechanism to continuously vibrate the crystal position. 
倍では, 共振器内の基本波の損失を十分に減らすことに よって, 基本波の50\%を超える出力を得ることが,解析的に 求められ, 実験的にも示された。この深紫外域の光源は微 細加工など多くの応用分野があるが, 装置としての寿命や 信頼性の向上がさらに必要とされる。

\section{謝 辞}

この研究の一部は新エネルギー産業技術開発機構 (NEDO)より委託を受けた事業として実施した。関係各位 のご協力に感謝する。

\section{参考文献}

1) D. Hon: in Laser Handbook Vol. 3 ed. M. L. Stitch, (North-Holland, Amsterdam, 1986) p.421.

2) D. Eimerl, L. Davis, S. Velsko, E. K. Graham, and A. Zalkin: J.
Appl. Phys. 62 (1987) 1968.

3) P. Huber: Opt. Commun. 15 (1975) 196.

4) K. Kato: IEEE J. Quantum Electron. QE-22 (1986) 1013.

5) H. Souma, T. Sato, T. Nishimata, and I. Shindo: Tech. Digest of 16th Int. Conf. Quantum Electron., Tokyo, 1988, PD-7 (Japan Soc. Appl. Phys., Tokyo, 1988) p.19.

6) G. D. Boyd and D. A. Kleinman: J. Appl. Phys. 39 (1968) 3597.

7) Y. Taira: Jpn. J. Appl. Phys. 31 (1992) L682.

8）伊沢孝男, 山村史彦, 内村龍三, 薬王輝雄: 応用物理 62 (1993) 911.

9) Y. Taira: Proc. CLEO, Baltimore, 1993 (OSA, Washington DC., 1993) p.634.

10) Y. Taira, K. Sueoka, Y. Mori, and T. Sasaki: Technical Digest of OSA Annual Meeting, Long Beach, 1997 (OSA, Washington DC., 1997).

11) R. Wallenstein: private communication (1992).

12) M. Hasegawa and Y. Taira: Proc. Int. Display Research Conference, Monterey 1994 (SID, New York, 1994) p.213.

13) F. Yamada, A. Nishikai, and Y. Taira: Digest of Tech. Papers SID Int. Symposium Vol. XXVIII, Boston, 1997 (SID, New York, 1997) p.715.
ベータホウ酸バリウム $\left(\beta \mathrm{BaB}_{2} \mathrm{O}_{4}\right)$ 結晶 $(\mathrm{BBO}$ crystal $)$

1軸性の非線型および電気光学結晶として, 中国のC. Chen らによって1980年代に発表された. 200nmまで透明で, 夕イ

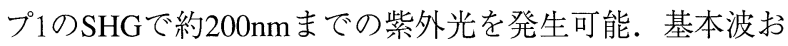
よび二倍波の吸収が極めて少なく,レーザー光強度に対す る耐性が高く, 屈折率の温度変化が少なく, 位相整合範囲 が大きいという特長を持ち,レーザーによる紫外光発生に 一大革命をもたらした，LBO, CLBO等のさきがけともい える結晶である。現在中国で大量に製造されており, SHG,
およびQースイッチ等に使用されている．結晶の対称性の ため90度位相整合では有効な非線型光学定数がゼロにな る。位相整合範囲が広いので結晶への入射角変化には敏 感であるが, 温度安定性が高く, 通常のSHGでは温度制御 は必要ない. 若干の潮解性があるが, 表面にARコートを施 し, 低湿度の環境であれば, 特別の空付きの容器なしで使 用できる。

(平 洋一) 